\title{
Quantifying the effect of Caspian tern predation on threatened and endangered Pacific salmon in the Columbia River estuary
}

\author{
Thomas P. Good*, Michelle M. McClure, Benjamin P. Sandford, \\ Katherine A. Barnas, Douglas M. Marsh, Brad A. Ryan, Edmundo Casillas
}

National Marine Fisheries Service, Northwest Fisheries Science Center, 2725 Montlake Boulevard East, Seattle, Washington 98112, USA

\begin{abstract}
Caspian terns Sterna caspia breeding in the Columbia River estuary exploit Pacific salmon Oncorhynchus spp. as prey, consuming millions of outmigrating juvenile salmonids annually. We analyzed recoveries of salmonid passive integrated transponder (PIT) tags from the East Sand Island tern colony to calculate predation rates (\% of available fish taken) on 4 Columbia and Snake River steelhead O. mykiss Evolutionarily Significant Units (ESUs). A life cycle modeling approach was used to estimate potential increases in ESU population growth rate $(\lambda)$ given potential reductions in Caspian tern numbers on East Sand Island. Reducing tern predation on steelhead ESUs by $50-100 \%$ increased $\lambda$ from 0.8 to $2.5 \%$, depending on the ESU and the reproductive contribution of hatchery fish, and assuming no compensatory mortality. This is comparable to survival improvements modeled for hydropower improvements in the basin but less than those modeled for harvest reductions. Reducing avian predation as part of an effort to reduce all sources of mortality may assist in ESU recovery. A thorough understanding of such predator-prey relationships is needed to manage conflicts between predators and their threatened and endangered Pacific salmonid prey.
\end{abstract}

KEY WORDS: Caspian tern · Pacific salmon · Predation · Life-cycle modeling · Lambda $(\lambda)$

\section{INTRODUCTION}

Wild, naturally reproducing salmon and steelhead Oncorhynchus spp. have declined dramatically throughout the US Pacific Northwest during the last $100 \mathrm{yr}$ (NRC 1996). Within the recognized species of Chinook $(O$. tshawytscha), coho (O. kisutch), chum (O. keta), pink (O. gorbuscha), and sockeye (O. nerka) salmon, and steelhead trout (O. mykiss), 52 Evolutionary Significant Units (ESUs; Waples 1991) have been identified, and half of them are listed under the US Endangered Species Act. In the Columbia River basin, 12 ESUs are listed under the Endangered Species Act, and $84 \%$ of the populations therein are not currently viable (McClure et al. 2003).

The orthodox explanation for the present Pacific salmonid crisis involves anthropogenic factors known as the 'H's' - commercial and recreational harvest of adults, habitat degradation, production of hatchery fish, and the direct and indirect effects of hydropower operations (NRC 1996, Stouder et al. 1997, Levin \& Schiewe 2001, Ruckelshaus et al. 2002b). However, factors such as predation by piscivorous birds, marine mammals and fishes (NMFS 2000, 2005), variability in ocean productivity (Mantua et al. 1997, Welch et al. 2000), and nonindigenous species (Fresh 1997) may also impede recovery. Life-cycle modeling indicates that mortality of juvenile salmonids during their freshwater and estuarine migration in particular may reduce adult returns (Beamesderfer et al. 1996) and constrains production in the Columbia River Basin (Kareiva et al. 2000).

Each year, from 60 to 100 million salmonid smolts outmigrate through the Columbia River estuary (NMFS 2004), where piscivorous birds nesting on islands consume anywhere from 4 to 12 million smolts annually (Roby et al. 1999, Collis et al. 2002a,b, 2003, Roby et al. 2003a,b). Avian predation of this magnitude 
on Pacific salmon has only recently been documented. Prior to 1984 , terns were not recorded nesting in the Columbia River estuary (Gill \& Mewaldt 1983), but few data exist on historical seabird populations. In 1984, approximately 1000 pairs nested on dredge material deposited on East Sand Island; in 1986, the terns moved to Rice Island, a dredge-spoil island upriver of East Sand Island (Cuthbert \& Wires 1999). During the 1990s, there was further northward and coastward range expansion (Cuthbert \& Wires 1999), which resulted in Caspian tern breeding colonies in the Columbia River estuary being the largest ever reported there (Shuford \& Craig 2002). As basin-wide losses of Pacific salmon juveniles to avian predators constitute a substantial proportion of some individual salmonid runs (Roby et al. 1998, IMST 1998), reducing avian predation in the estuary is one way to reduce mortality during this critical life stage and to potentially increase salmonid population growth rates.

Following studies suggesting that Caspian tern colonies in the estuary posed a risk to recovery for some Pacific salmon ESUs (Roby et al. 1998, Collis et al. 1999), the breeding colony on Rice Island was relocated 15 miles $(24 \mathrm{~km})$ downriver to East Sand Island beginning in 1999 (Roby et al. 2002, Suryan et al. 2004), where alternative prey (primarily Pacific herring and anchovies) were more available. The proportion of salmonids in the terns' diet ( 76 to $90 \%$ on Rice Island) declined after colony relocation (33 to $47 \%$ on East Sand Island) (Roby et al. 2002), and estimates of salmonid consumption declined from 12.4 million (95\% CI $=9.1$ to 15.7 million) in 1998 , when the colony was entirely on Rice Island, to 7.3 million (95\% CI $=6.1$ to 8.6 million) in 2000, when the entire colony was on East Sand Island (Collis et al. 2001, USFWS 2001).

Despite the reduced consumption of juvenile salmonids accomplished via colony relocation, Caspian terns on East Sand Island still consume more than 4 to 8 million smolts annually (Collis et al. 2005). While relocation influenced the relative proportion of salmonids in the diet, the East Sand Island colony remains large, and the Caspian tern breeding season overlaps with outmigration of Chinook, coho, sockeye and chum salmon, and steelhead juveniles (Fig. 1). The energetic demands of breeding Caspian terns $\left(220 \mathrm{~g}_{\text {fish }} \mathrm{d}^{-1}\right.$ or roughly $1 / 3$ of their body weight) (Collis et al. 2002c) forces adults to secure fish prey from the estuary, many of which are juvenile Pacific salmon.

The relationship between Caspian tern abundance and salmonid consumption is not known with certainty; however, estimating this relationship is critical for management actions predicated on reducing predation via managing predator numbers. Predation impact may respond to predator numbers in a variety of ways. It may increase linearly with increasing predator numbers, due to a relatively constant per capita consumption. Such a linear increase is often assumed from the literature or laboratory experiments, and has been used for fish consumption estimates (Coutin \& Reside 2003). Alternatively, predation impact may increase or decrease in response to predator numbers in a non-linear fashion, due to prey saturation of predators, aggregative behavior, or predator competition (Cosner et al. 1999, Skalski \& Gilliam 2001). Finally, predation may cause an immediate reduction in total survival, in which case it is considered an additive mortality factor, or it may cause no reduction in total survival until it reaches some threshold value, in which case it is considered a compensatory factor (Pöysä 2004). Meaningful management of predator populations not only requires estimating the relationship of predator impact to predator numbers; predictions must also be in the currency of Pacific salmon recovery, so that predation impact can be translated into potential changes in population growth $(\lambda)$ of salmon and steelhead ESUs.

The objectives of our analyses were to (1) calculate annual predation rates on Pacific salmonids (\% of available fish consumed) by Caspian terns breeding in the Columbia River estuary (specifically East Sand Island); (2) to estimate the relationship between annual predation rates and the number of Caspian terns breeding on East Sand Island; and (3) to assess the potential increase in steelhead population growth rate $(\lambda)$ that would correspond to proposed reductions in the size of this Caspian tern colony.

\section{MATERIALS AND METHODS}

Study site. We focused our study on East Sand Island, the largest Caspian tern colony in North America, and the time period from 1999 to 2003, which was

\begin{tabular}{|l|l|l|l|l|l|l|l|l|l|l|l|l|}
\hline & J & F & M & A & M & J & J & A & S & O & N & D \\
\hline Steelhead & & & & & & & & & & & & \\
\hline Fall Chinook & & & & & & & & & & & & \\
\hline Spring/Summer Chinook & & & & & & & & & & & & \\
\hline Coho & & & & & & & & & & & & \\
\hline Sockeye & & & & & & & & & & & & \\
\hline Chum & & & & & & & & & & & & \\
\hline Caspian terns & & & & & & & & & & & & \\
\hline
\end{tabular}

Fig. 1. Arrival times (month) of juvenile salmonids and breeding season of Caspian terns in the Columbia River estuary 
primarily after the colony had been relocated from Rice Island. East Sand Island is located in the Columbia River estuary at river-km 8 (Fig. 2); it is a $1.8 \mathrm{~km}$ long natural island, although it has been used as a dredge spoil disposal site. The colony on East Sand Island is located on 1.2 ha of open sand on the east end of the island. The Caspian tern population in the estuary grew from 1000 breeding pairs in 1984 to more than 9900 pairs in 2002 and is presently located entirely on East Sand Island (Fig. 3). Population estimates on Caspian tern colonies in the Columbia River estuary were made using aerial photographs taken near the end of the incubation period (see Collis et al. 2002a for details). Estimates used in our analyses were updates of published data for the time period 1999 to 2003 (Roby et al. 1999, Collis et al. 2002a,b, 2003, Roby et al. $2003 a, b)$ obtained from the authors (D. D. Roby and D. E. Lyons, pers. comm.). In addition to Caspian terns, a large colony of double-crested cormorants exists on the west end of the island (Roby et al. 2002).
Bonneville Dam is located at river-km 235 (Figs. 2 \& 4) and is the last Columbia River impoundment to be encountered by outmigrating Pacific salmon juveniles before they enter the estuary. The estimates of available juvenile prey used are compiled from PIT tagged fish that enter the estuary via the juvenile bypass system or via release from barges that transport them around upstream dams. Juvenile salmonids outmigrating from the Columbia River basin include those from Snake River, Upper Columbia River, Middle Columbia River, Lower Columbia River and Upper Willamette River ESUs (Fig. 4).

Analysis of PIT-tag data. To calculate predation rates, we obtained information on tagging and release dam sites, and in-river passage for PIT-tagged salmonids from the Passive Integrated Transponder Tag Information System (PTAGIS; see www.ptagis.org). This site is managed by the Pacific States Marine Fisheries Commission (www.ps mfc.org), an organization that helps resource agencies and the fishing industry

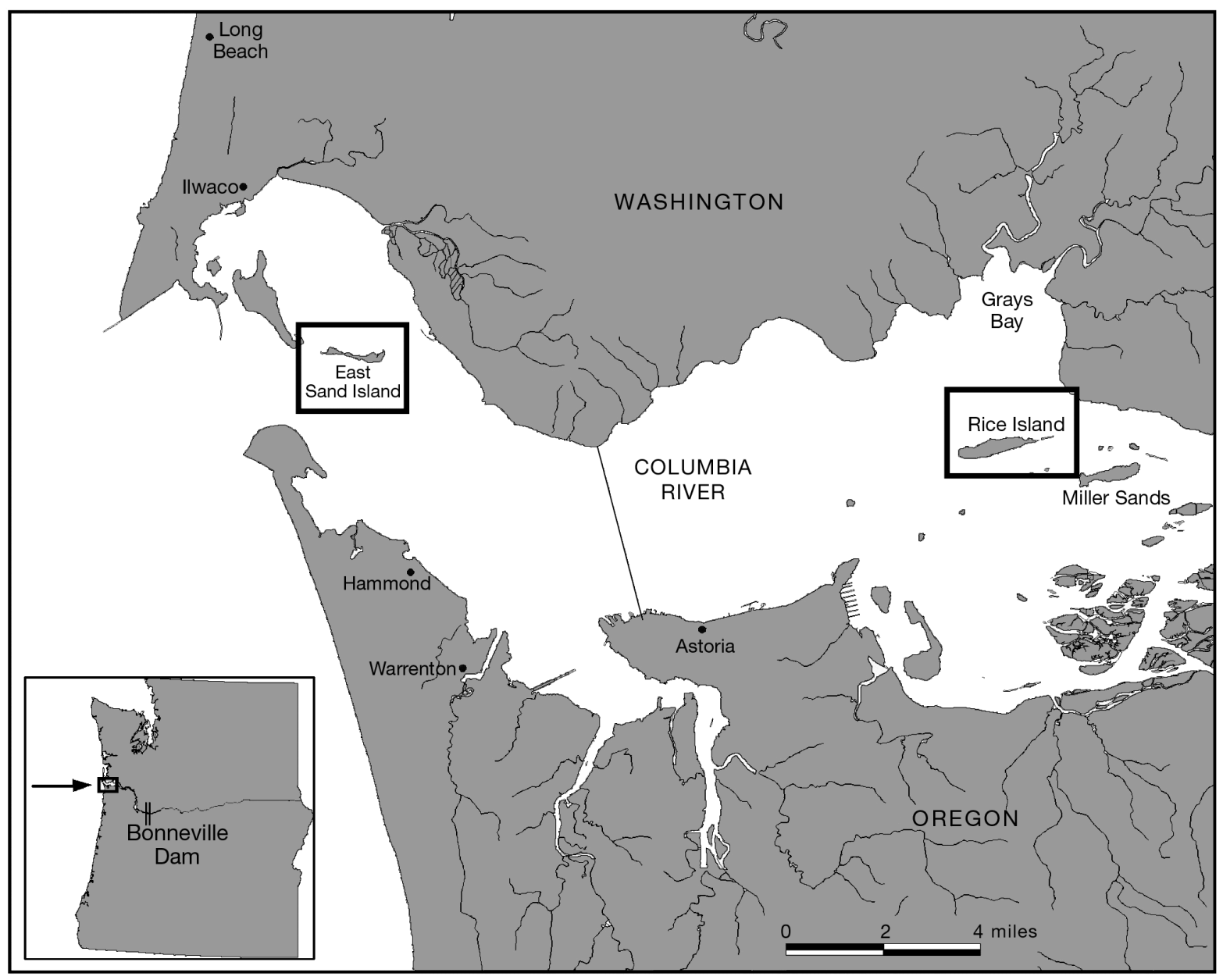

Fig. 2. Columbia River estuary showing the locations of East Sand Island, site of the only currently active Caspian tern nesting colony in the Columbia River estuary and downstream of the Astori Bridge (solid line crossing river), and Rice Island, a former Caspian tern nesting colony 


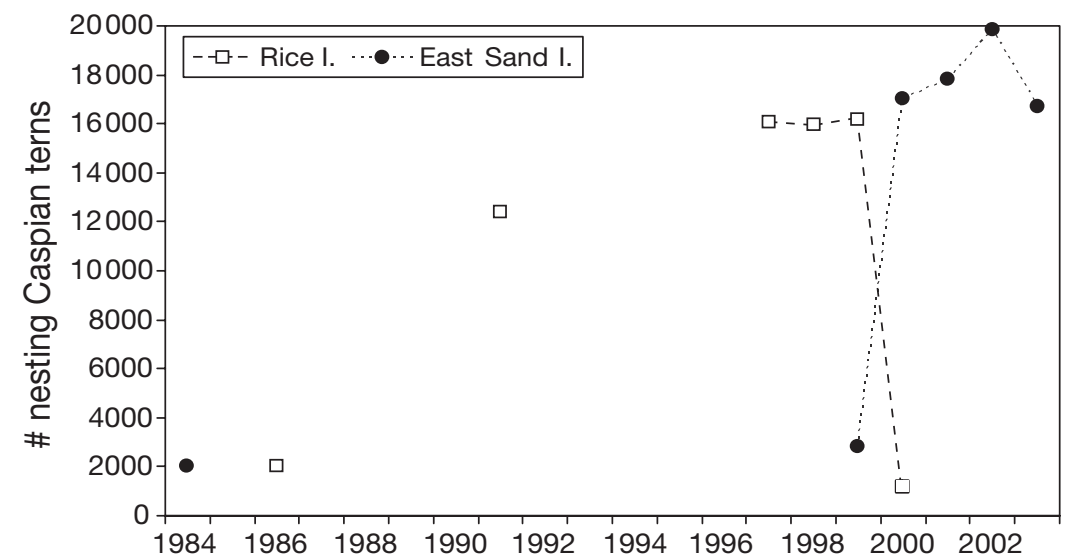

Fig. 3. Numbers of Caspian terns nesting on islands in the Columbia River estuary since 1984. Data provided by Columbia River Bird Research (Roby et al. 1999, 2003a,b, Collis et al. 2002a,b, 2003, D. D. Roby \& D. E. Lyons, pers. comm.)

manage fishery resources in California, Oregon, Washington, Idaho and Alaska. Pacific salmon PIT tags were recovered from the Caspian tern colony on East Sand Island during systematic annual scans under the supervision of one of the authors (B. Ryan; for detailed methods see Ryan et al. 2001). Information from individual PIT tags recovered was then obtained from
PTAGIS, including migration year (in our case 1999 to 2003), release location, and rearing type (hatchery-raised or wild). We also obtained records of PITtagged juveniles detected as they passed through the juvenile bypass system or were transported and released below Bonneville Dam.

We focused our analyses on steelhead Oncorhynchus mykiss, because predation rates (the proportion of available fish taken) on outmigrating juvenile steelhead are (a) the highest of all the Pacific salmon species (Ryan et al. 2003, Roby et al. 2003b) and (b) are similar on hatchery-raised and wild-origin fish (Collis et al. 2001, Ryan et al. 2001). It is assumed that benefits to the most impacted species (steelhead) that may result from reduced predation by East Sand Island Caspian terns will also benefit other listed Pacific salmon ESUs. To determine the source ESU, recovered PIT tags were assigned to steelhead ESUs (Snake River, Upper Columbia River, Middle Columbia River, Lower Columbia River; see Fig. 4) based on hatchery and release location for hatchery fish and capture-

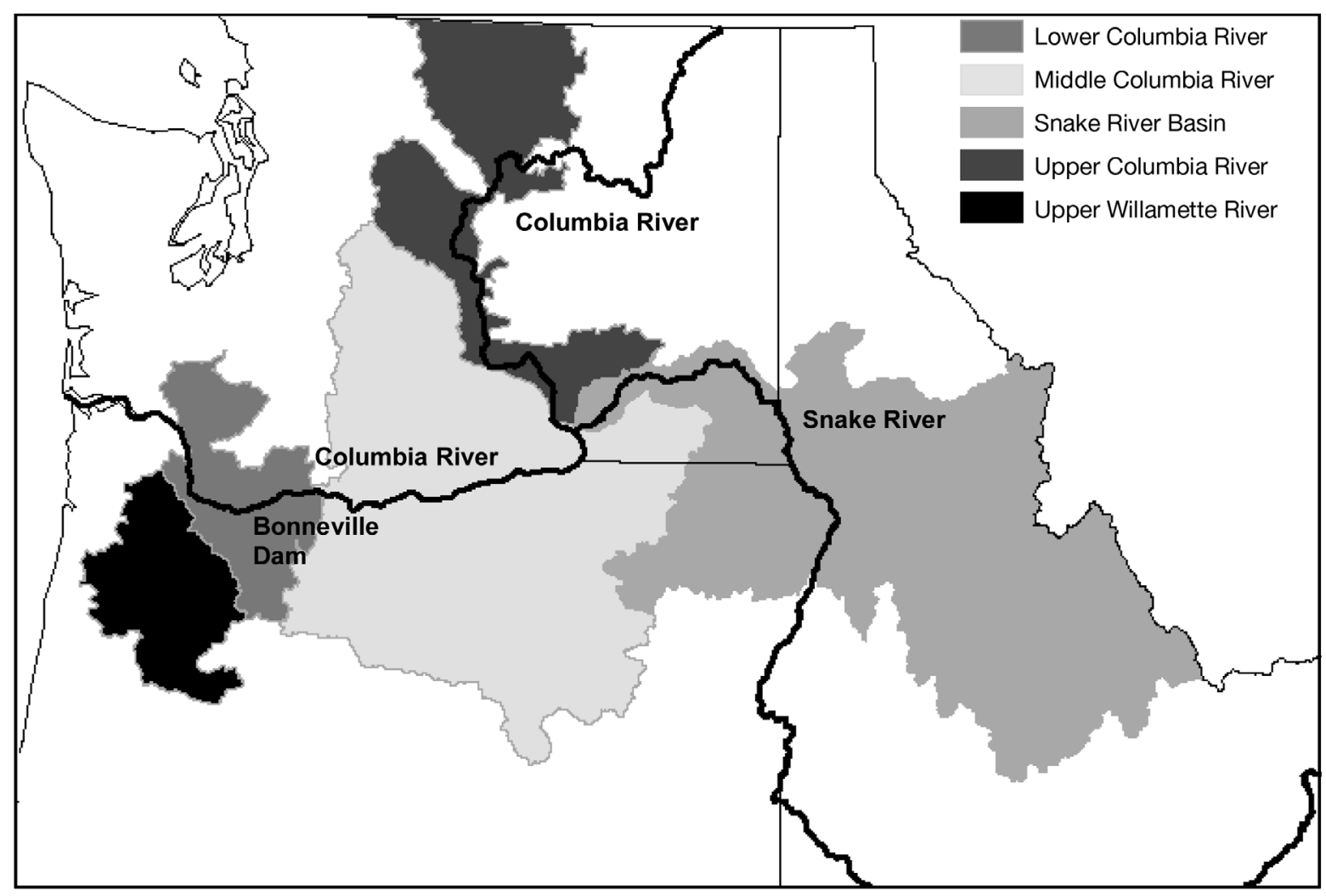

Fig. 4. Columbia River Basin showing the locations of the Endangered Species Act (ESA)-listed steelhead Evolutionary Significant Units (ESUs) (Lower Columbia River, Upper Willamette River, Middle Columbia River, Upper Columbia River and Snake River) 
release location for wild fish. The Lower Columbia River ESU was comprised of PIT-tagged fish detected at Bonneville Dam as well as experimental hatchery releases in the estuary below Bonneville Dam; no records were available for the Upper Willamette River ESU, which lies entirely below Bonneville Dam.

We calculated predation rates as the percentage of available fish consumed in the estuary (\# of PIT tags detected on the East Sand Island Caspian tern colony/\# PIT-tagged fish detected at or transported below Bonneville Dam $\times$ 100) (Ryan et al. 2001, 2003). PIT tag-derived estimates of this sort are generally considered minimum estimates, as an unknown number of tags deposited on the island are removed by wind and water erosion, damaged, or undetected because tags in close proximity to one another create electronic interference (Ryan et al. 2001, Collis et al. 2001, 2002). It is also unknown how many PIT tags ingested by piscivorous birds are regurgitated or defecated off the colony at roosting or loafing sites (Ryan et al. 2001, 2003). On East Sand Island, present protocols result in high tag detection rates $(95 \%$; B. Ryan unpubl. data). Tag removal protocols are minimizing tag interference issues, but the number of tags deposited off the colony remains unknown.

Statistical analyses. To determine the relationship between predation rates and predator number, we conducted regression analyses of annual predation rates for 4 of the 5 Columbia River basin steelhead ESUs combined and individually on the number of Caspian terns breeding on East Sand Island. We modeled the relationship through the origin, based on the assumption that if no terns nested on East Sand Island, then there would be no tern predation of steelhead from that colony. We included data from 1999, when both the number of predators nesting on East Sand Island and predation rate were much smaller than from 2000 to 2003, which provided valuable insight into the predator-predation rate relationship on the island at a small colony size. Including the 1999 data exerted little influence (discrepancy or leverage) on the regression analyses, as long as the relationship was modeled through the origin (P. Wilson, USFWS, unpubl. data).

Life cycle modeling. To assess the potential increase in steelhead population growth rate corresponding to a reduced size of the East Sand Island Caspian tern colony, we used the median population growth rate lambda $(\lambda)$ calculated for the 4 ESUs in McClure et al. (2003). The methods used to derive $\lambda$ have been developed for data sets with high sampling error and agestructure cycles (Holmes 2001), extensively tested using simulations for threatened/endangered populations and low-risk stocks (Holmes 2004), and cross-validated with time series data (Holmes \& Fagan 2002). Population growth rate is an essential parameter in viability assessments and an important predictor of extinction risk. Calculating population growth rate in an annualized manner provides a standard metric for comparison between conservation units such as species or ESUs.

We calculated the deterministic change in $\lambda$ for ESUs given standard reductions in mortality from Caspian tern predation. Because the vast majority of steelhead in the interior Columbia are semelparous, the percent increase in $\lambda$ attributable to an increase in survival at a particular life history stage can be approximated as:

$$
\Delta \lambda=\left[\left(\frac{S_{\text {new }}}{S_{\text {old }}}\right)^{1 / G}-1\right] \times 100
$$

where $S_{\text {old }}$ is the initial survival rate before recovery action, $S_{\text {new }}$ is the survival rate following the recovery action, and $G$ is the average generation time (McClure et al. 2003). This calculation assumes that the change in survival due to tern predation is independent of density and of changes in survival elsewhere in the salmonid life history.

We modeled potential changes in $\lambda$ using the regression of ESU predation rate on the number of Caspian terns breeding on East Sand Island from 1999 to 2003 and assuming the potential reduction in tern numbers would start from 10000 pairs (there were 9933 pairs in 2002). Regressions for all ESUs were based on data from 1999 to 2003; the Upper Columbia River ESU was also modeled excluding data from 2001, when sample size for available prey was extremely low ( 100 tags, while other years had >500 tags), making the very high estimate of predation rate suspect. We then calculated the percent increase in salmonid population growth rate corresponding to incremental reductions in the tern breeding pairs (i.e. from 10000 to 9375 , to 8750 , to 8125 , to $7500 \ldots$ ). Calculations assumed that mortality from Caspian tern predation on juvenile steelhead is additive and resulted in maximum estimates of the potential benefits of reduction in tern predation.

Finally, we present the potential effect of reductions in Caspian tern predation on steelhead ESU population growth rates using estimates of $\lambda$ that span the likely influence of hatchery production. We followed previous analyses (McClure et al. 2003) in using an optimistic estimate $\left(\lambda_{0}\right)$ that assumed that hatchery-origin spawners had zero reproductive success, while the most pessimistic estimate $\left(\lambda_{h}\right)$ assumed that hatcheryorigin spawners had reproductive success equivalent to that of natural-origin spawners, thereby masking natural-origin population trends. Empirical studies indicate that hatchery-origin spawning fish generally have lower (and perhaps much lower) reproductive success than natural-origin spawners (see reviews by 
Reisenbichler \& Rubin 1999 and Berejikian \& Ford 2004); however, this difference can vary considerably across species and populations, and it is very rare that data are available for a particular population of interest. The methods we used to assess alternative likely tern predation scenarios have been used in similar analyses of other mortality factors affecting Pacific salmon in the Columbia River basin (McClure et al. 2003), and allow us to compare the relative impact of these actions in a common currency.

\section{RESULTS}

Annual predation rates ( $\%$ of available PIT-tagged steelhead consumed) for the 4 ESA-listed Columbia River basin steelhead ESUs examined varied among years (Table 1), but generally increased with increasing numbers of Caspian terns breeding on East Sand Island (Fig. 5). Regression analyses found a significant linear response of predation rate to Caspian tern numbers on East Sand Island for the Snake River, Upper Columbia River, and Middle Columbia River steelhead ESUs (Fig. 5a-c; Table 2). The Upper Columbia River ESU did not show a linear response when 2001 data was included, but it did after removing the 2001 data (Table 2), when sample sizes were very low (see 'Materials and methods'). The Lower Columbia River steelhead ESU showed a marginally significant linear response (Fig. 5d, Table 2); however, we were cautious to reject the model for this ESU due to low power $(1-\beta=0.37)$.

The potential for increase in population growth rate $(\lambda)$ also varied among the 4 steelhead ESUs, with the Upper Columbia River steelhead ESU deriving the greatest benefit from reducing the calculated Caspian Tern predation rate. The potential increase in population growth rate among ESUs ranged from $0.8 \%$ (Lower Columbia River ESU) to $1.3 \%$ (Upper Columbia River ESU) if the Caspian Tern colony was reduced to 5000 pairs and from $1.6 \%$ (Lower Columbia River
ESU) to $2.5 \%$ (Upper Columbia River ESU) if the tern colony was reduced to zero (Table 3 ).

\section{DISCUSSION}

Our analyses indicate that a substantial proportion of PIT-tagged steelhead were consumed annually from 1999 to 2003 by Caspian terns breeding on East Sand Island in the Columbia River estuary, building on the results of previous evaluations (Roby et al. 1998, Collis et al. 2001, 2002b, Ryan et al. 2001, 2003). While the relocation efforts significantly reduced the proportion of salmon and steelhead in the breeding season diet of these terns (Roby et al. 2002), our analyses show that East Sand Island terns still annually consume 5 to $10 \%$ of the outmigrating PIT tagged steelhead that reach the estuary, depending upon the ESU. Our calculations also likely underestimate actual predation rates; although $95 \%$ of tags experimentally dispersed on this colony are detected (B. Ryan unpubl. data), the number of tags deposited off the colony remains unknown.

Our use of a linear relationship to describe estimates of predation rate and the number of Caspian terns nesting on East Sand Island admittedly represents the most parsimonious explanation of the data in hand. However, relatively constant per capita consumption rates over the large range of tern numbers on East Sand Island support this interpretation. Mean per capita consumption for adults breeding on East Sand Island in 2000 (431 smolts tern ${ }^{-1}$ ) was virtually the same as that calculated for 1999 (437 smolts tern ${ }^{-1}$; D. Roby \& D. Lyons, Oregon State University, unpubl. data), even though the colony was almost 5 times bigger in 2000 than in 1999. Constant per capita consumption rates for adult terns were not limited to East Sand Island; mean per capita consumption for adults breeding on Rice Island in 2000 (740 smolts tern ${ }^{-1}$ ) was virtually the same as in 1999 (784 smolts tern ${ }^{-1}$; D. Roby and D. Lyons, Oregon State University, unpubl. data), even though colony relocation reduced numbers in 2000 to a

Table 1. Number of steelhead PIT tags detected at or transported below Bonneville Dam, number of PIT tags detected in the East Sand Island Caspian tern colony, and Caspian tern predation rates calculated as the ratio of steelhead taken (\# of PIT tags detected on the East Sand Island tern colony) to those available in the Columbia River estuary (\# PIT-tagged fish detected at or transported below Bonneville Dam $\times 100$ ) (from Ryan et al. 2001, 2003). ESU abbreviations: SR = Snake River; UCR = Upper Columbia River; $\mathrm{MCR}=$ Middle Columbia River; LCR = Lower Columbia River; Total = total of the 4 ESUs

\begin{tabular}{|c|c|c|c|c|c|c|c|c|c|c|c|c|c|c|c|}
\hline \multirow[t]{2}{*}{ Year } & \multicolumn{5}{|c|}{ \# PIT tags at Bonneville Dam } & \multicolumn{5}{|c|}{ \# PIT tags on East Sand Island } & \multicolumn{5}{|c|}{ — Predation rate $(\%)$} \\
\hline & SR & UCR & MCR & LCR & Total & SR & UCR & MCR & $\mathrm{LCR}$ & Total & SR & UCR & MCR & LCR & Total \\
\hline 1999 & 66691 & 15769 & 632 & 1233 & 84325 & 484 & 86 & 3 & 5 & 578 & 0.73 & 0.55 & 0.47 & 0.41 & 0.69 \\
\hline 2000 & 38023 & 5347 & 368 & 1119 & 44857 & 2207 & 586 & 24 & 51 & 2868 & 5.80 & 10.96 & 6.52 & 4.56 & 6.39 \\
\hline 2001 & 18235 & 116 & 871 & 3159 & 22381 & 1302 & 30 & 88 & 213 & 1633 & 7.14 & 25.86 & 10.10 & 6.74 & 7.30 \\
\hline 2002 & 35046 & 571 & 231 & 2924 & 38772 & 3713 & 53 & 21 & 183 & 3970 & 10.59 & 9.28 & 9.09 & 6.26 & 10.24 \\
\hline 2003 & 34682 & 50818 & 211 & 3017 & 85728 & 3712 & 4984 & 16 & 281 & 8712 & 10.70 & 9.81 & 7.58 & 9.31 & 10.14 \\
\hline
\end{tabular}




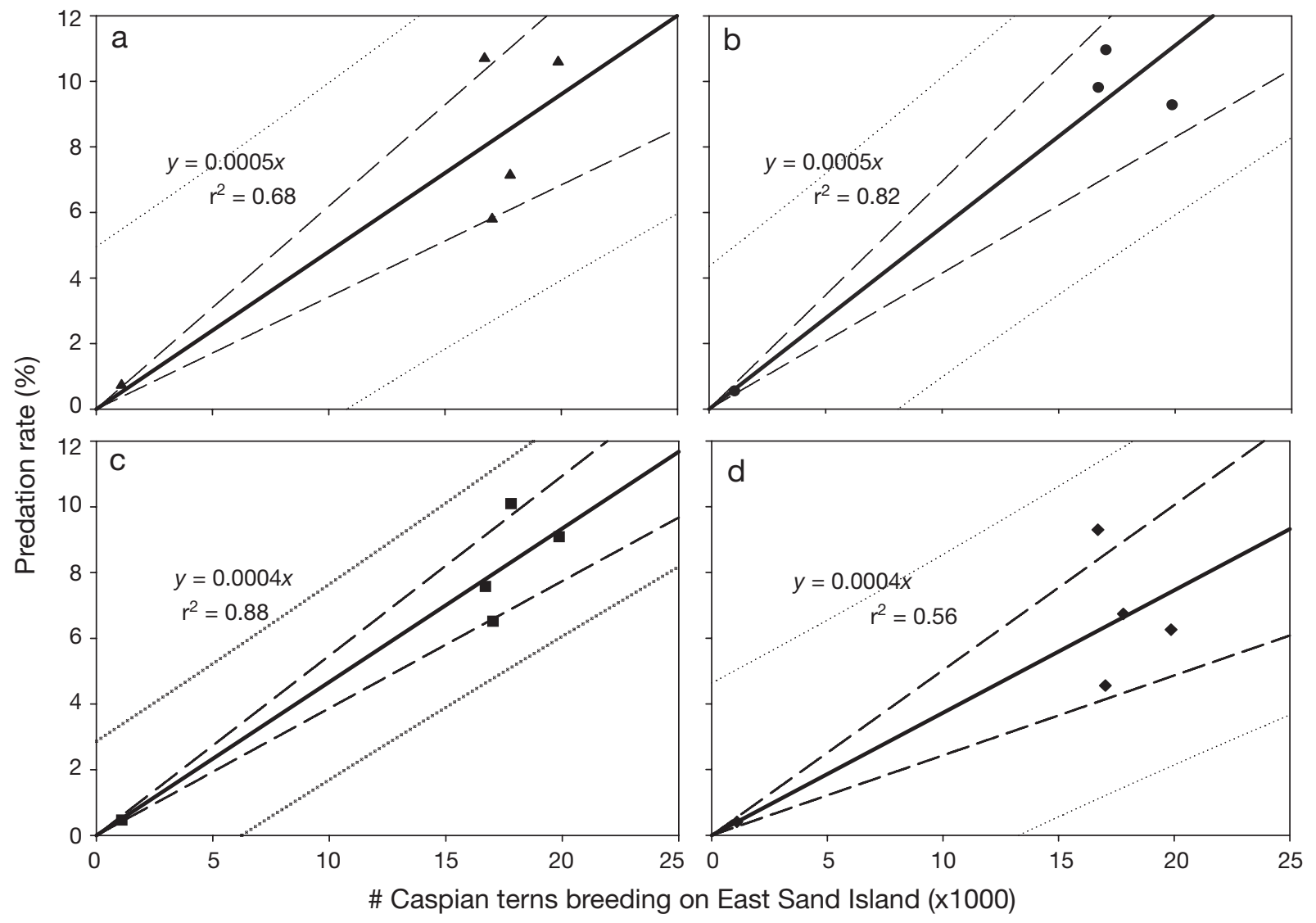

Fig. 5. Linear regression of predation rates (\% of tags detected at or transported below Bonneville Dam which were later detected on East Sand Island) on the number of Caspian terns breeding on East Sand Island (1999 to 2003) for the (a) Snake River steelhead ESU (triangles), (b) Upper Columbia River steelhead ESU (circles), (c) Middle Columbia River steelhead ESU (squares), and (d) Lower Columbia River steelhead ESU (diamonds). Dashed lines $=95 \%$ confidence bands; dotted lines $=95 \%$ prediction bands

tenth of what they were in 1999. The constant per capita consumption rates at both locations might be expected if both colonies were considered one foraging population whose overall numbers were relatively constant from 1999 to 2003. However, Caspian terns foraging downriver consume fewer juvenile Pacific salmon than terns foraging upriver (Collis et al. 2002), and Rice

Table 2. Linear regressions of predation rate (\% of available PIT-tagged fish later detected on the East Sand Island tern colony) on the number of Caspian terns breeding on East Sand Island for the 4 Columbia River basin steelhead ESUs examined

\begin{tabular}{|lcrrrc|}
\hline & df & SS & MS & $F$ & p \\
\hline All ESA-listed steelhead & 1,4 & 50.8 & 50.8 & 15.5 & 0.03 \\
Snake River ESU & 1,4 & 51.3 & 51.3 & 9.6 & 0.05 \\
Upper Columbia River ESU & 1,4 & 136.1 & 136.1 & 2.1 & 0.25 \\
UCR (excluding 2001) & 1,3 & 62.8 & 62.8 & 21.5 & 0.04 \\
Middle Columbia River ESU & 1,4 & 51.5 & 51.5 & 29.1 & 0.01 \\
Lower Columbia River ESU & 1,4 & 29.1 & 29.1 & 6.1 & 0.09 \\
\hline
\end{tabular}

Island terns consumed more Pacific salmon than East Sand Island terns, which is exactly why colony relocation worked (Roby et al. 2002). It is thus likely that the linear relationship we observed in our data reflects predators with relatively unlimited prey over the limited time of the breeding season and the range of nesting Caspian tern numbers observed to date.

Life-cycle modeling indicates that reducing the number of nesting Caspian terns on East Sand Island has the potential to increase steelhead population growth rates considerably. Under the most pessimistic scenarios explored, where hatchery fish reproduce at the same rate as natural-origin fish $\left(\lambda_{\mathrm{h}}\right.$ in Table 3), the Snake River and Middle Columbia River ESUs population growth rates could get closer to self-sustaining (i.e. $=1$ ) with a complete reduction of Caspian tern predation at East Sand Island. The Upper Columbia 


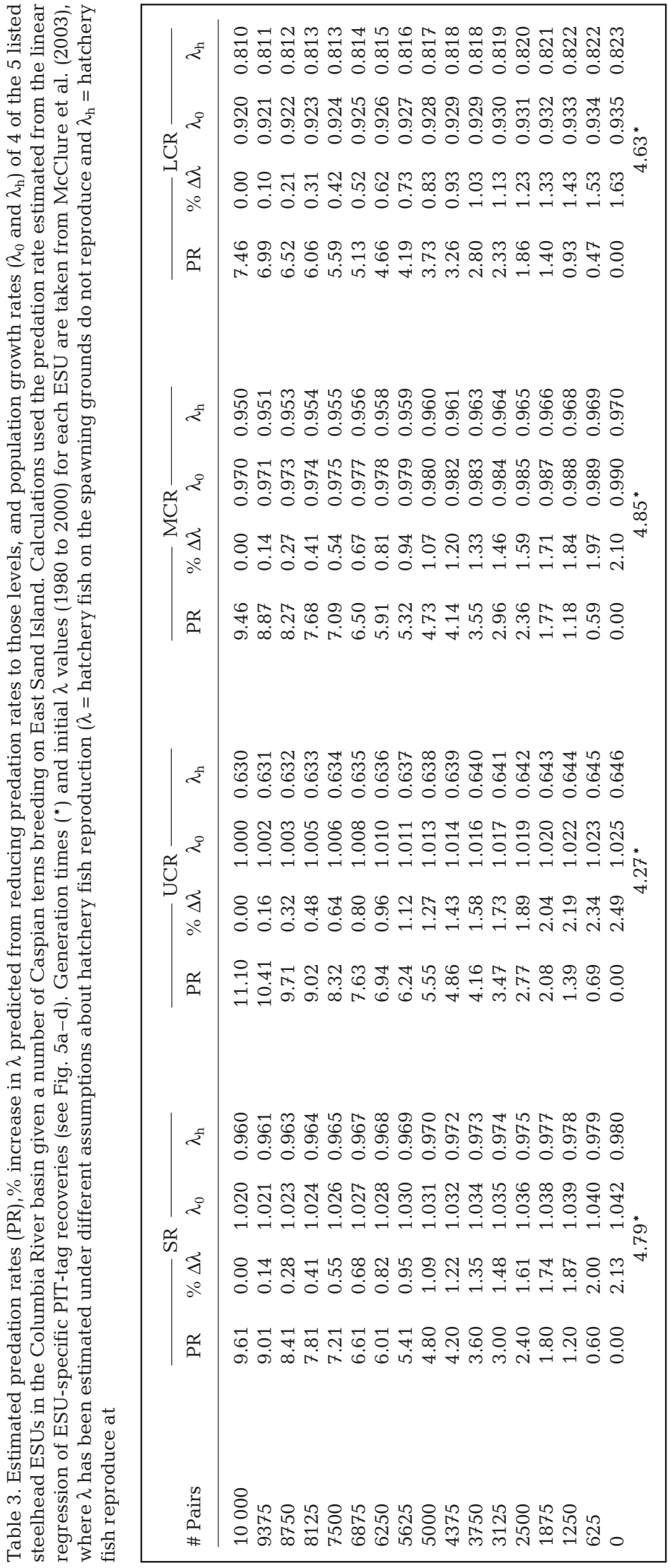

River ESU is well below self-sustaining under the pessimistic scenario and likely has the most potential to benefit from reduced tern predation (Roby et al. 2003b). Benefits to the Lower Columbia River steelhead ESU were smaller, no doubt due to the relatively low predation rates on that ESU.

Similar modeling exercises have estimated potential increases in population growth rates in Columbia River salmon and steelhead ESUs by reducing mortality from hydropower or harvest operations. The estimates for hydropower improvement ( 0 to $4 \%$ for steelhead ESUs; McClure et al. 2003) would result from mandated changes to improve passage for both adults and juveniles (NMFS 2000). The estimates for harvest elimination (4 to $8 \%$ for steelhead ESUs) have been largely realized already (McClure et al. 2003). Potential increases in $\lambda_{0}$ that may be realized from eliminating Caspian tern predation (1.6 to $2.5 \%$ ) are thus in the same range as those of other recovery strategies in the Columbia River basin.

Calculations made in our analyses assume that mortality from Caspian tern predation on juvenile steelhead is additive and that the benefits from any reduction in tern predation are fully realized. As with the analyses of hydropower or harvest mortality reductions (McClure et al. 2003), one cannot assume a one-for-one increase in Pacific salmon populations by reducing any single source of mortality if this mortality source is compensated for by other sources of mortality. Similar life-cycle modeling of predation effects of Caspian terns breeding on Rice Island in 1997 to 1998 (Roby et al. 2003b) considered 3 scenarios: that mortality was 0, 50, and $100 \%$ additive. However, life-cycle modeling of predation effects of Caspian terns breeding on Crescent Island in the mid-Columbia River (Antolos et al. 2005) assumed predation was $100 \%$ additive (no other mortality factors compensated for the estimated reductions in tern predation). Our estimates of the level of improvements in steelhead population growth associated with potential reductions in Caspian tern predation based on a given predation rate, are maximum likely values; any compensatory component of tern predation on outmigrating juveniles would reduce the gains to steelhead populations estimated here.

Calculations also assume that the PIT-tagged juveniles that underlie our analyses on the 
whole fairly represent their ESUs. Should similarities between propagation (wild vs. hatchery-origin), transportation (barging vs. running the river) and season (early vs. late migration) deviate considerably from those observed for these steelhead ESUs (Collis et al. 2001, Ryan et al. 2003), then the expected benefits to the entire ESU will reflect that deviation.

The extent of predation experienced by Pacific salmon in the Columbia River basin highlights the need to focus on quantifying predation impacts where possible. Double-crested cormorants Phalacrocorax auritis in the Columbia River estuary now rival Caspian terns in population size and annual salmonid consumption (Anderson et al. 2004, Collis et al. 2005). Bird colonies upriver of the estuary also pose a predation risk. Predation at the Crescent Island colony is such that completely eliminating the tern colony could improve $\lambda$ by $1.1 \%$ for the Upper Columbia River steelhead ESU, assuming $100 \%$ additive mortality (Antolos et al. 2005). Caspian terns commuting to the river from off-river colonies consume substantial numbers of outmigrating salmonid juveniles, particularly the Upper Columbia River steelhead ESU (Good et al. 2006). Northern pikeminnow Ptychocheilus oregonensis, a native fish predator whose populations have dramatically increased, consume millions of juvenile salmonids annually throughout the Columbia River basin (Beamesderfer et al. 1996). Active management to reduce their predation may result in improvements in $\lambda$ of 0.4 to $0.7 \%$ (assuming $100 \%$ additive mortality; Roby et al. 2003b). Non-indigenous fish predators in the system include walleye Sander vitreus, smallmouth bass Micropterus dolomieui and channel catfish Ictalurus punctatus; however, estimates of salmonid consumption are spotty (NRC 2004). Food web modeling to assess relative contributions of salmonid predators in the John Day Reservoir on the Columbia River found that juvenile mortality from Caspian Terns and northern pikeminnow was more critical for salmon and steelhead survival than was control of non-indigenous smallmouth bass, channel catfish, and walleye (Harvey \& Kareiva 2005). Ultimately, comprehensive analyses need to make use of information on all sources of predation in addition to factors that affect those predation rates, such as hatchery releases and water levels during the juvenile outmigration (Antolos et al. 2005) as well as the extent of compensatory mortality experiences by Pacific salmon juveniles during the critical outmigration stage.

Finally, not all threatened and endangered salmonid populations in the Columbia River basin or elsewhere in the Pacific Northwest have declined because of the same factors or combination of factors; thus, not all populations or ESUs can be expected to respond positively to any particular management measure or com- bination of measures. Benefits to steelhead ESUs are assumed to translate to other threatened and endangered ESUs in the basin; however, the response of Chinook, sockeye, and chum salmon ESUs to management of avian predators in the Columbia River basin may not be proportional to the mitigated predation on steelhead. Additional factors may influence the gains in population growth rate that may be realized from reducing Caspian tern predation rates on outmigrating juvenile salmonids. These include, but are not limited to, hydropower operations, harvest rates, habitat conditions, the influence of hatchery fish and exotic species, ocean conditions, and climate change, as well as the extent to which mortality from Caspian terns is compensatory. While management of the East Sand Island Caspian tern colony will not, by itself, secure the recovery of Pacific salmon populations, it may form an important part of a broad management approach to reducing mortality that can rebuild threatened and endangered salmon and steelhead ESUs in the Columbia River basin.

Acknowledgements. We thank Paul Wilson of U.S. Fish and Wildlife Services for communication on influence statistics. Many years of PIT-tag recovery data would not exist without the hard work of the diligent field crews working for Brad Ryan, nor would they have been possible without funding from the Bonneville Power Administration and the U. S. Army Corps of Engineers.

\section{LITERATURE CITED}

Anderson CD, Roby DD, Collis K (2004) Conservation implications of the large colony of double-crested cormorants on East Sand Island, Columbia River estuary, Oregon, USA. Waterbirds 27:155-160

Antolos M, Roby DD, Lyons DE, Collis K, Evans AF, Hawbecker M, Ryan BA (2005) Caspian tern predation on juvenile salmonids in the mid-Columbia River. Trans Am Fish Soc 134:466-480

Beamesderfer RCP, Ward DL, Nigro AA (1996) Evaluation of the biological basis for a predator control program on northern squawfish (Ptychocheilus oregonensis) in the Columbia and Snake Rivers. Can J Fish Aquat Sci 53: 2898-2908

Berejikian BA, Ford MJ (2004) Review of relative fitness of hatchery and natural salmon. US Dept of Commerce, NOAA Tech Memo NMFS-NWFSC-61

Collis K, Adamany SL, Roby DD, Craig DP, Lyons DE (1999) Avian predation on juvenile salmonids in the lower Columbia River. Avian predation on juvenile salmonids in the lower Columbia River: 1998 Annual Report. Available at: www.columbiabirdresearch.org

Collis K, Roby DD, Craig DP, Ryan BA, Ledgerwood RD (2001) Colonial waterbird predation on juvenile salmonids tagged with passive integrated transponders in the Columbia River estuary: vulnerability of different salmonid species, stocks and rearing types. Trans Am Fish Soc 130:385-396

Collis K, Roby DD, Lyons DE, Suryan RM, Antolos M, Anderson SK, Myers AM, Hawbecker M (2002a) Caspian 
tern research on the Lower Columbia River: Final 2000 Season Summary. Available at: www.columbia birdresearch.org

Collis K, Roby DD, Lyons DE, Suryan RM, Antolos M, Anderson SK, Myers AM, Hawbecker M (2002b) Caspian tern research on the Lower Columbia River: Final 2001 Summary. Available at: www.columbiabirdresearch.org

Collis K, Roby DD, Craig DP, Adamany SL, Adkins JY, Lyons DE (2002c) Colony size and diet composition of piscivorous waterbirds on the Lower Columbia River: Implications for losses of juvenile salmonids to avian predation. Trans Am Fish Soc 131:537-550

Collis K, Roby DD, Couch C, Dorsey G, and 5 others (2003) Caspian tern research on the Lower Columbia River: Final 2002 Season Summary. Available at www. columbiabirdresearch.org

Collis K, Roby DD, Couch C, Dorsey G and others (2005) Piscivorous waterbird research on the Columbia River: Final 2004 season summary. Available at: www. columbiabirdresearch.org

Cosner C, DeAngelis DL, Ault JS, Olson DB (1999) Effects of spatial grouping on the functional response of predators. Theor Popul Biol 56:65-75

Coutin PC, Reside J (2003) Fish predation by great cormorants, Phalacrocorax carbo carboides, in the Gippsland Lakes, south-eastern Australia. In: Cowx IG (ed) Interactions between fish and birds: implications for management. Blackwell Science, Oxford, p 196-210

Cuthbert FJ, Wires LR (1999) Caspian tern (Sterna caspia). In: Poole A, Gill F (eds) The birds of North America, No. 403. The birds of North America Inc., Philadelphia, PA

Fresh KL (1997) The role of competition and predation in the decline of Pacific salmon and steelhead. In: Stouder DJ, Bisson PA, Naiman RJ (eds) Pacific salmon and their ecosystems: status and future options. Chapman \& Hall, New York, p 245-275

Gill RE, Mewaldt LR (1983) Pacific coast caspian terns: dynamics of an expanding population. Auk 100:369-381

Good TP, Harstad DL, Hall CA, Ryan BA, Carper M, Maranto CJ (2006) Predation on juvenile salmonids by Caspian terns nesting in Potholes Reservoir: Appendix in: Research, monitoring, and evaluation of avian predation on salmonid smolts in the Lower and Mid-Columbia River: Draft 2005 season summary (Roby DD, Collis K, Adkins JY, Couch C, Courtot B, Lord R, Lyons DE, Suzuki Y, Evans A, Hawbecker M (2006). Available at: www. columbiabirdresearch.org

Harvey CJ, Kareiva PM (2005) Community context and the influence of non-indigenous species on juvenile salmon survival in a Columbia River reservoir. Biol Invasions 7: 651-663

Holmes EE (2001) Estimating risks in declining populations with poor data. Proc Natl Acad Sci USA 98:5072-5077

Holmes EE (2004) Beyond theory to application and evaluation: diffusion approximations for population viability analysis. Ecol Appl 14:1272-1293

Holmes EE, Fagan WF (2002) Validating population viability analysis for corrupted data sets. Ecology 83:2379-2386

IMST (Independent Multidisciplinary Science Team) (1998) Pinniped and seabird predation: implications for recovery of threatened stocks of salmonids in Oregon under the Oregon Plan for salmon and watersheds. Tech Rep 1998-2 to the Oregon Plan for salmon and watersheds. Governor's Natural Resources Office, Salem, OR

Kareiva P, Marvier M, McClure M (2000) Recovery and management options for spring/summer chinook salmon in the Columbia River Basin. Science 290:977-979
McClure MM, Holmes EE, Sanderson BL, Jordan CE (2003) A large-scale, multispecies status assessment: anadromous salmonids in the Columbia River Basin. Ecol Appl 13: 964-989

NMFS (National Marine Fisheries Service) (2000) Operation of the federal Columbia River power system including the juvenile fish transportation program and the Bureau of Reclamation's 31 projects, including the entire Columbia Basin Project. U. S. Department of Commerce, NOAA, National Marine Fisheries Service, Northwest Region, Seattle, WA

NMFS (National Marine Fisheries Service) (2005) Caspian tern predation on juvenile salmonid out migrants in the Columbia River estuary. Appendix C in Caspian tern management to reduce predation of juvenile salmonids in the Columbia River estuary: final environmental impact statement (USFWS, USACE, and NMFS) January 2005

NRC (National Research Council) (1996) Upstream: salmon and society in the Pacific Northwest. National Academy Press, Washington, DC

NRC (National Research Council) (2004) Managing the Columbia River: instream flows, water withdrawals, and salmon survival. Committee on water resources management, instream flows, and salmon survival in the Columbia River Basin, Water Science and Technology Board, Board on Environmental Studies and Toxicology, Division on Earth and Life Studies. National Research Council of the National Academies, Washington, DC

Pöysä H (2004) Ecological basis of sustainable harvesting: is the prevailing paradigm of compensatory mortality still valid? Oikos 104:612-615

Reisenbichler RR, Rubin SP (1999) Genetic changes from artificial propagation of Pacific salmon affect the productivity and viability of supplemented populations. ICES J Mar Sci 56:459-466

Roby DD, Craig DP, Collis K, Adamany SL (1998) Avian predation on juvenile salmonids in the Lower Columbia River: 1997 Annual Report. Available at: www. columbiabirdresearch.org

Roby DD, Craig DP, Lyons DE, Collis K, Adkins J (1999) Caspian Tern predation on juvenile salmonids in the Columbia River estuary. 1999 interim report. Available at: www.columbiabirdresearch.org

Roby DD, Collis K, Lyons DE, Craig DP, Adkins JY, Myers AM, Suryan RM (2002) Effects of colony relocation on diet and productivity of Caspian terns. J Wildl Manag 66: 662-673

Roby DD, Collis K, Couch C, Dorsey G and 7 others (2003a) Caspian tern research on the lower Columbia River: Final 2003 season summary. Available at: www. columbiabirdresearch.org

Roby DD, Lyons DE, Craig DP, Collis K, Visser GH (2003b) Quantifying the effects of predators on endangered species using a bioenergetics approach: Caspian terns and juvenile salmonids in the Columbia River estuary. Can J Zool 81:250-265

Ryan BA, Ferguson JA, Ledgerwood RD, Nunnallee EP (2001) Detection of passive integrated transponder tags from juvenile salmonids on piscivorous bird colonies in the Columbia River Basin. N Am J Fish Manag 21:417-421

Ryan BA, Smith SG, Butzerin JM, Ferguson JW (2003) Relative vulnerability to avian predation of juvenile salmonids tagged with passive integrated transponders in the Columbia River estuary, 1998-2000. Trans Am Fish Soc 132: 275-288

Shuford WD, Craig DP (2002) Status assessment and conservation recommendations for the Caspian tern (Sterna 
caspia) in North America. U.S. Department of the Interior, Fish and Wildlife Service. Portland, OR

Skalski GT, Gilliam JF (2001) Functional responses with predator interference: viable alternatives to the Holling Type II model. Ecology 82:3083-3092

Suryan RM, Craig DP, Roby DD, Chelgren ND, Collis K, Shuford WD, Lyons DE (2004) Redistribution and growth of the Caspian tern population in the Pacific coast region of North America, 1981-2000. Condor 106:777-790

USFWS (US Fish and Wildlife Service) (2001) Seabird predation and salmon recovery in the Columbia River estuary.

Editorial responsibility: Rory Wilson,

Swansea, UK
US Fish and Wildlife Service, Portland, OR

USFWS (US Fish and Wildlife Service), USACE (U.S. Army Corps of Engineers), and NMFS (National Marine Fisheries Service) (2005) Caspian tern management to reduce predation of juvenile salmonids in the Columbia River estuary: final environmental impact statement. Jan 2005. Available at: http://migratorybirds.pacific.fws.gov/CATE _FEIS_document_pdf_files.htm

Waples RS (1991) Pacific salmon, Oncorhynchus spp., and the definition of 'species' under the Endangered Species Act. Mar Fish Rev 53(3):11-22

Submitted: July 28, 2006; Accepted: January 2, 2007

Proofs received from author(s): February 23, 2007 